Tарасенко Кирил. Заголовки романів письменника-єлизаветинця Генрі Робертса ....

УДК: 82.09:311.8:821.111

DOI: https://doi.org/10.32840/2225-479X.2019.31-32.3

Тарасенко Кирил

(м. Запоріжжя)

\title{
Заголовки романів \\ письменника-слизаветинця Генрі Робертса в контексті ренесансної традиції
}

У иій статті проаналізовано заголовки романів письменникаєлизаветиния Генрі Робертса «Виклик Фортуні» (1590) та «Феандер. Цнотливий Лицар» (1595) крізь призму нових аналітичних підходів.

Продемонстровано, щзо заголовки романів Робертса - доволі складні для розуміння компоненти тексту, оскільки вони $\epsilon$ структурно-розлогими, багатоскладовими та містять імпліцитні смисли, які можна розкодувати за допомогою апелящії до ренесансних культурних практик, тогочасних літературних конвенцій. Осмислення письменницьких інтениій крізь призму категорій «горизонт авторських сподівань» та «горизонт читачького очікування» дозволяє виявити характер корелячії заголовків зі специффікою художнього мислення автора. Аналіз назв романів Робертса з урахуванням аналітичного досвіду рецептивної естетики показав, щео на рівні заголовку автор твору вдається до гри з читацькими очікуваннями.

В иій історико-літературній розвідиі також розширено розуміння функиіонального потенціалу заголовків творів Робертса. Виявлено здатність заголовків відігравати не тільки такі традиційні функиії як номінативно-сюжетна і характерологічно-персонажна, $a$ й декларативно-метафоричну, інтригуюче-ігрову та комериійну. Показано, щзо письменник використовує різноманітні підходи до зачікавлення читацької авдиторії, представники якої належали здебільшого до неаристократичних кіл єлизаветинського суспільства.

Ключові слова: заголовок, англійський пізньоренесансний роман, Генрі Робертс, єлизаветинська доба. 


\section{I. Історико-літературний прощес}

У сучасному вітчизняному літературознавстві англійська пізньоренесансна романістика вже давно змінила свій статус із «маловивченого художнього феномену» ${ }^{1}$ на активно досліджуваний фрагмент літературного поля, що знаходиться в точці перетину двох векторів розвитку жанру ("romance" та “novel"). Про це свідчить і низка вітчизняних досліджень, присвячених таким літературним персоналіям, як Філіп Сідні (В. Шереметьєва ${ }^{2}$ ), Джон Лілі (Л. Привалова ${ }^{3}, \quad$ Н. Торкут $\left.{ }^{4}\right)$, Джордж Гаскойн $\left(\right.$ О. Лілова $\left.{ }^{5}\right)$, Томас Делоні (Т. Власова $\left.{ }^{6}\right)$, Томас Неш (Л. Федоряка $\left.{ }^{7}\right)$, Томас Лодж (Н. Торкут $\left.{ }^{8}\right)$, Ентоні Манді

${ }^{1}$ Торкут Н. М. Проблеми генези і структурування жанрової системи англійської прози пізнього Ренесансу (малі епічні форми та “література факту"). - Запоріжжя, 2000. - С. 5.

2 Шереметьєва В. К. Творчість Філіпа Сідні в соціокультурному контексті англійського Ренесансу: дис. ... канд. філол. наук: 10.01 .04 «Література зарубіжних країн». - Дніпропетровськ, 2017 - 247 с.

${ }^{3}$ Привалова Л. П. Основные жанровые особенности модификации английского романа последней трети XVI в.: автореф. дис. ... канд. филол. наук: 10.01.05 «Литература стран Западной Европы, Америки и Австралии». - Москва, 1988. - 24 с.

${ }^{4}$ Торкут Н. М. Джон Лілі - законодавець літературної моди: творча біографія на тлі епохи // Ренесансні студії. - Запоріжжя : КПУ, 2011. Вип. 16-17. - С. 25-56.

${ }^{5}$ Лілова О. С. Особливості поетики творчості Джорджа Гасконя: дис. ... канд. філол. наук: 10.01.04 «Література зарубіжних країн». - Київ, 2003. $241 \mathrm{c.}$

${ }^{6}$ Власова Т И. Проблема жанрового своеобразия «Романа о суконщиках» Т. Делони как разновидности английского ренессансного романа: автореф. дис. ... канд. филол. наук: 10.01.05 «Литература стран Западной Европы, Америки и Австралии». - Москва, 1985. - 24 с.

7 Федоряка Л. Д. Творчі пошуки Томаса Неша-сатирика в культурному контексті англійського Ренесансу : дис. ... канд. філол. наук: 10.01.04 «Література зарубіжних країн». - Дніпропетровськ, 2009. - 238 с.

${ }^{8}$ Торкут Н. Н. Особенности поэтики романов Т. Лоджа: дис. .. канд. филол. наук: 10.01.05 «Литература стран Западной Европы, Америки и Австралии». - Москва, 1991. - 244 с; Торкут Н. М. Томас Лодж: життєвий шлях, літературна репутація і творчі здобутки // Ренесансні студії. Запоріжжя : КПУ, 2018. - Вип. 29-30. - С. 3-21. 
$\left(\right.$ (Г. Штефан $\left.{ }^{9}\right)$, Генрі Робертс (К. Тарасенко $\left.{ }^{10}\right) .3$ появою нових методологій літературознавчого аналізу романістика єлизаветинської доби зазнає певного рецептивного переосмислення.

Одним із елементів, що привертає увагу дослідників, $€$ заголовок англійського пізньоренесансного художнього твору. Адже саме заголовок вважається «першою ознакою тексту, що дає читачеві перше уявлення про книгу» ${ }^{11}$, його також називають «ключем до інтерпретації тексту» ${ }^{2}$ $\mathrm{i}$ «категорією поетики» ${ }^{13}$. Та якщо назви сучасних романів здебільшого є звичними і зрозумілими для читачів, то поетика заголовків англійських пізньоренесансних романів - це, скоріше, загадка або, навіть, своєрідний квест для більшості з них.

Тож актуальність цього дослідження визначається потребою подальшого наукового осмислення ренесансної традиції називання художнього твору, зокрема й оригінального досвіду тих літераторів, що орієнтувалися на максимально широку читацьку авдито- рію. Саме до таких "men of letters" i належав письменникєлизаветинець Генрі Робертс.

Предметом безпосереднього аналізу обрано назви романів Г. Робертса «Виклик Фортуні» $(1590)^{14}$ та

${ }^{9}$ Штефан А. А. Літературна спадщина Ентоні Манді: специфіка взаємодії традиції і новаторства: дис. ... канд. філол. наук: 10.01.04 «Література зарубіжних країн». - Дніпропетровськ, 2008. - 232 с.

${ }^{10}$ Тарасенко К. В. Романістика Генрі Робертса в контексті англійської прози пізнього Ренесансу: дис. ... канд. філол. наук: 10.01.04 «Література зарубіжних країн». - Дніпропетровськ, 2009. - 224 с.

11 Ламзина A. В. Заглавие // Литературоведение. Литературное произведение. Основные термины и понятия. URL: http://taviak.ru/distance/wpcontent/uploads/2014/obshcheobrazovatelnye_distsipliny/Literatura/Chernec.pdf.

12 Эко У. Заметки на полях «Имени розы» // Эко У. Имя розы. - М. : Книжная палата, 1989. - С. 428.

13 Джанджакова E. О поэтике заглавий // Лингвистика и поэтика. - М. : Наука, 1979. - С. 208.

14 Детальніше про цей роман див: Тарасенко К. В. Специфіка репрезентації гендерної проблематики в романі Генрі Робертса «Виклик Фортуні» 
«Феандер. Цнотливий Лицар» $(1595)^{15}$. Ця стаття покликана пунктирно окреслити наявні в англійській ренесансній прозі тенденції називання літературних творів i запропонувати свіжий погляд на заголовки творів Генрі Робертса - автора, який орієнтувався на художні смаки не елітарної читацької публіки.

Мета статті - висвітлити специфіку творчого експерименту Г. Робертса в царині поетики заголовка 3 урахуванням як культурних практик та літературних конвенцій ренесансної доби, так і читацьких очікувань.

У сучасному літературознавстві існує чимало наукових розвідок, присвячених аналізу поетики заголовка художнього твору (А. Ламзіна ${ }^{16}$, Е. Джанджакова ${ }^{17}$,

(1590) // Ренесансні студії / відп. ред. Торкут Н. М. - Запоріжжя : КПУ, 2010. - Вип. 14-15. - С. 155-166; Тарасенко К. В. Специфіка інтерпретації романічних кліше в англійському пізньоренесансному формульному романі (на матеріалі твору Генрі Робертса «Виклик Фортуні» (1590)) // Вісник Запорізького державного університету: збірник наукових статей. Серія: «Філологічні науки» / гол. ред. Білоусенко П. І. - Запоріжжя, 2010. - № 1 - С. 77-83; Тарасенко К. В. Специфіка репрезен- тації культурних кодів англійського Ренесансу в романі Генрі Робертса «Виклик Фортуні» (1590) // Ренесансні студії / відп. ред. Торкут Н. М. - Запоріжжя : КПУ, 2012. - Вип. 18-19. - С. 96-108; Тарасенко К. В. Специфіка репрезентації екзильної тематики в романі Генрі Робертса «Виклик Фортуні» (1590) // Держава та регіони: науково-виробничий журнал. Серія: «Гуманітарні науки» / гол. ред. Н. М. Торкут. - Запоріжжя : КПУ. - 2018.- № 1. - С. $22-$ 26.

${ }^{15}$ Детальніше про цей роман див: Тарасенко К. В. Специфіка жанровостильової організації роману Генрі Робертса «Феандер. Цнотливий лицар» (1595) // Держава та регіони: науково-виробничий журнал. Серія: «Гуманітарні науки» / гол. ред. В. Д. Буряк. - Запоріжжя. - 2010.- № 3. С. 31-35; Тарасенко K. В. «Формульна» природа роману Генрі Робертса «Феандер. Цнотливий лицар» (1595) // Держава та регіони: наукововиробничий журнал. Серія: «Гуманітарні науки» / гол. ред. В. Д. Буряк. Запоріжжя. - 2012.- № 2. - С. 24--30; Тарасенко К. В. Специфіка репрезентації жіночої тематики в романі Генрі Робертса «Феандер» (1595) // Вісник МДУ. Серія «Філологія» - Маріуполь : Маріупольський державний університет. - 2018.- № 18. - С. 108-113.

16 Ламзина А В. Цит. вид.

${ }^{17}$ Джанджскова Е. Цит. вид. - С. 208. 
О. Немировська ${ }^{18}$, О. Волковинський ${ }^{19}, \quad$ I. Кузнєцова ${ }^{20}$, I. Бехта і О. Сподарик ${ }^{21}$, В. Мережинський ${ }^{22}$ та ін.). Усі дослідники акцентують увагу на тому, що заголовок $\epsilon$ важливою складовою тексту, і аналізують різні його аспекти (часопросторовий, алюзивний, лігнвістичний, інтертектуальний, смисловий, концептуальний та ін.). Науковці розмежовують різні типи заголовків художнього твору. Так, приміром, А. Ламзіна виокремлює наступні чотири типи:

- заголовки, що презентують тему або ідею твору;

- заголовки, що задають сюжетну перспективу твору;

- персонажні заголовки;

- заголовки, які позначають час та простір ${ }^{23}$.

У рамках цієї класифікації більшість назв ренесансних романів можуть бути віднесені до другого або третього типу. Втім, творчі інтенції та експерименти тогочасних літераторів важко вписуються у «прокрустове ложе» чітких дефініцій чи класифікацій, адже логіка художнього мислення за часів Відродження суттєво відрізнялася від сучасної. Думається, що застосування комплексу аналітичних процедур, що включає співвісне-

${ }^{18}$ Немировська О. Ф.Заголовок як актуалізатор художнього часу і простору (на матеріалі роману О. Т. Гончара «Собор»).

URL: http://nbuv.gov.ua/UJRN/Mova_2012_17_28.

19 Волковинський О. С. Алюзивний заголовок фейлетонів Остапа Вишні як запрошення до комунікативної гри автора з реципієнтом.

URL: http://nbuv.gov.ua/UJRN/Nzizh_2014_54_26.

${ }^{20}$ Кузнєцова I. В. Заголовок-алюзія: смисловий і концептуальний аспекти (на матеріалі англомовних художніх творів XX-XXI століть). URL: http://nbuv.gov.ua/UJRN/VZhDU_2014_5_34.

${ }^{21}$ Бехта I. A. Сподарик О. В. Заголовок у смисловому просторі британського постмодерністського художнього тексту.

URL: http://nbuv.gov.ua/UJRN/Nznuoaf_2016_62_15.

${ }^{22}$ Мережвинський B. Поетика заголовків драматичних творів Лесі Українки. URL: http://dspace.nbuv.gov.ua/bitstream/handle/123456789/11274/06Merzhevynsky.pdf?sequenc.

${ }^{23}$ Ламзіна А В. Цит. вид. 


\section{I. Історико-літературний прощес}

сення моделі називання твору із типом художньої свідомості ренесансного автора (міфологічна, традиційналістська, індивідуально-авторська), виявлення кореляції заголовку із популярними в ті часи культурними практиками, а також використання новітніх методологій літературознавчого аналізу, дозволять поглибити наші знання про заголовок як важливий паратекстуальний елемент художньої твору.

Слизаветинський роман привертає увагу науковців не тільки яскравою жанрово-стилістичною палітрою та оригінальністю інтерпретацій сюжетних схем, але й специфічними заголовками, характерними рисами яких $\epsilon$ розгорнутість, багатослівність та багатоскладовість. В умовах розширення читацької авдиторії, коли літератори боролися за увагу читача, вдалий заголовок міг забезпечити книзі успішний продаж. Саме тому письменники ще у назві намагалися якомога цікавіше представити тематику твору, аби заінтригувати потенційного реципієнта.

Перший роман Генрі Робертса, як і більшість тогочасних творів, має розгорнуту й багатослівну назву: «Виклик Фортуні. Проголошений Андруджіо, иляхетним гериогом Саксонським, який розповідає про нещзастя, постійні зіткнення з мінливою Фортуною та вигнання, якого зазнав він сам, його дружсна й діти. Також додається опис уславлених війн Галастіно, герцуога Міланського, який мститься підступним саксонцям за несправедливість. Тут зображено шляхетне терпіння, рідкісний зразок благопристойної стриманості та ідеальний взіреизь справжньої дружби. Дуже приємний та насичений перипетіями» ${ }^{24}$. («A Defiance to Fortune.

${ }^{24}$ Roberts $H$. A Defiance to Fortune // Eine kritische edition von Henry Roberts "A Defiance to Fortune" (1590) / Inaugural-Dissertation zur Erlangung des Doktorgrades der Philosophischen Fakultät der Universität zu Köln / [vorgelegt von Giselger Tiegel aus Münstenberg]. - Köln : Universität zu Köln, 1973. P. 131. 
Proclaimed by Andrugio, noble Duke of SAXONY, declaring his miseries, and continually crossed with vconstant Fortune, the banishment of himselfe, his wife and his children. Whereunto is adioined the honorable Warres of Galastino, Duke of Millaine in reuenge of his wrongs vpon the trayterous Saxons. Wherein is noted a myrrour of noble patience, a most rare example of modest chastity, and the perfect patterne of true friendship. Verie delectable and ful of varietie» ${ }^{25}$ ).

Твір було написано у 1590 році, коли Робертс, випробувавши себе в ролі автора памфлетів, звернувся до більш престижного в плані авторської самореалізації жанру - роману. В цей час помітно розширювалося коло читачів: до представників аристократії та інтелектуальної еліти, які завжди вважали читання обов'язковою культурною практикою, приєднувалися представники третього стану (дрібні буржуа, джентрі, йомени, ремісники, торгівці), які поступово почали долучатися до такої вельми престижної форми дозвілля. Цьому значною мірою сприяли: підвищення освітнього рівня середньостатистичного англійця, який тепер мав можливість отримати освіту у граматичних школах, розвиток книгодрукування та поширення книготоргівлі. Як зазначає Н. Вілл, «за період із середини до кінця XVI століття спостерігалося стрімке зростання кількості опублікованих книг: якщо в 1558-1579 в Лондоні було надруковано 3850 текстів, то за наступні два десятиліття їхня кількість зросла до 7430» ${ }^{26}$. Як припускає дослідник творчості Г. Робертса Л. Райт, «автор, ймовірно, розраховував на те, що його потенційні читачі будуть представниками

25 Тут і в подальшому переклад роману мій $-\boldsymbol{K} . \boldsymbol{T}$.

${ }^{26}$ Wheale N. Writing and society: Literacy, Print and Politics in Britain (15901660). - London : Routledge, 1999. - P. 6. 


\section{I. Історико-літературний прощес}

неаристократичних кіл єлизаветинського суспільства» ${ }^{27}$. Зауважимо, що в ситуації постійної конкуренції між єлизаветинськими літераторами молоді автори повинні були слідкувати за тенденціями тогочасної літературної моди та застосовувати всі відомі засоби, аби зацікавити читацьку аудиторію, смаки якої формувалися під впливом перекладів геліодорівського і рицарського романів, континентальної новели тощо. Комерційний успіх літературного твору значною мірою залежав від вдало підібраного заголовку, від того, чи співпадуть сподівання автора 3 очікуваннями потенційного читача.

Тож бачиться доцільним розглянути поетику заголовку першого роману Генрі Робертса із застосуванням дослідницьких стратегій рецептивної естетики. Адже рецептивна естетика «представляє літературний текст як продукт історичної ситуації, що залежить від позиції читача, який інтерпретує цей текст. Саме цим пояснюється особливий інтерес рецептивної естетики до явищ масової культури (розважально-тривіальної літератури, газетно-журнальної продукції, коміксів та ін.)» ${ }^{28}$. Рецептивна естетика, яка сприяє проясненню ключових для інтерпретації позицій - позиції автора і позиції потенційного читача - послуговується терміном "Erwartungshorizont", який зазвичай перекладають як «горизонт очікування». Оскільки у ньому виокремлюються дві амбівалентні складові, які корелюють з одним із учасників комунікації - автором та читачем, то доцільною бачиться диференціація «горизонту очікування» на «горизонт авторських сподівань» і «горизонт читацьких очікувань». «Горизонт авторських сподівань», втілених у тексті,

\footnotetext{
${ }^{27}$ Wright L. Henry Roberts: patriotic propagandist and novelist // Studies in Philology. - 1932. - № 32. - P. 194.

${ }^{28}$ Дранов А. В. Рецептивная эстетика // Современное зарубежное літературоведение. Страны Западной Европы и США. Концепции, школы, термины. - М. : Интрада, 1996. - С. 127.
} 
означає комплекс естетичних, соціально-політичних, психологічних та інших уявлень, які визначають ставлення автора, а в силу цього і твору, до суспільства ${ }^{29}$. «Горизонт читацького очікування» - це специфічна схильність читача до певного жанру, яку автор так чи інакше враховує ${ }^{30}$.

У заголовку твору Г. Робертса міститься своєрідний «меседж» автора своєму потенційному читачеві, запрошення до своєрідного інтелектуального діалогу. Тут відчувається авторська гра 3 популярними в добу Ренесансу ідеями, 3 широким комплексом асоціацій, породжуваних концептом Фортуни. Письменник був певен, що пересічний читач має сприйняти довгий i багатоскладовий заголовок як належне, адже саме такі назви були тоді, як то кажуть в наші часи, у тренді. Подібні заголовки були типовими для творів, народжених в епоху традиціоналістської художньої свідомості. Зазвичай автор наслідував певний канон, однак іноді можна було спостерігати й прояви індивідуальноавторської художньої свідомості в окремих елементах тексту, зокрема у назві твору. 3 огляду на пунктуацію та змістову наповненість структурних компонентів назви роману Г. Робертса, в ній можна виокремити чотири структурно-композиційні блоки.

У першому блоці («Виклик Фортуні»), який можна назвати декларативно-метафоричним, автор, як і більшість єлизаветинських романістів, згадує ключове для твору поняття. Зазначимо, що концепт Фортуни за часів Ренесансу був надзвичайно популярним, його апологетикою була просякнута уся атмосфера доби, що характеризувалася стрімким розвитком капіталістичних відносин, великими географічними відкриттями та прискоренням соціальної мобільності. Кмітливий i

\footnotetext{
${ }^{29}$ Там само. - C. 31 .

30 Там само. - C. 32.
} 


\section{I. Історико-літературний процес}

винахідливий розум підштовхував індивіда до активних дій: відкривалися широкі обрії для життєвого й творчого ентузіазму. Шлях до успіху ставав дедалі коротшим, але водночас i небезпечнішим. Можна було здійснити успішну морську подорож та забезпечити собі фінансові статки на все життя, або ж, скориставшись вдалим збігом обставин, досягти омріяної мети. Втім, іноді колізії долі виявлялися вельми драматичними чи навіть трагічними. Тож закономірно, що саме 3 Фортуною пов'язувалися раптові збіги обставин та карколомні події, нечувані злети й драматичні падіння, оскільки саме вона поставала у свідомості ренесансної людини як «єдиний вірогідний шлях пояснити те, що було за межами розуміння індивіда» ${ }^{31}$.

Варто зауважити, що переклад назви згаданого твору Робертса українською мовою - це своєрідний перекладацький виклик (challendge), що спонукає до активізації знань із різних галузей філологічної науки: історії літератури, когнітивної лінгвістики та власне перекладознавства. Без з'ясування когнітивного змісту цього метафоричного і структурно-розлогого заголовку важко визначити відповідний спосіб відтворення його смислу при перекладі. Думається, що найбільш адекватним варіантом перекладу першої частини заголовку «A Defiance to Fortune» $\epsilon$ саме «Виклик Фортуні», оскільки він зберігає авторський концепт: зацікавити читацьку аудиторію актуальною ідеєю та сформувати певні читацькі очікування.

Заголовки, в яких згадувався популярний в ренесансну добу концепт Фортуни, були досить поширеною культурною практикою в ті часи. Тож природно, що й письменники-єлизаветинці іноді виносили його на титульні сторінки своїх творів. «Жіночий Гомер» Роберт

${ }^{31}$ Барг М. А. Эпохи и идеи: Становление историзма. - М. : Мысль, 1987. C. 240. 
Грін, приміром, сподівався привернути до свого роману увагу читачів заголовком «Арбасто. Анатомія Фортуни» (1584), Джон Лілі назвав один із своїх творів «Любов та Фортуна» (1589), а Брайан Мелбенк - «Філоцимус. Війна між Природою та Фортуною» (1589). Слизаветинський читач без особливих зусиль міг виявити зв'язок між назвами згаданих творів та їхнім змістом, адже авторська позиція в заголовках задекларована з усією очевидністю.

Що стосується назви роману Г. Робертса, то вона не декларує наміру автора проаналізувати сутність Фортуни (як Р. Грін), чи протиставити іiі іншим категоріям (як Дж. Лілі та Б. Мелбенк), вона лише створює певну інтелектуальну інтригу. У пересічного читача при знайомстві із таким заголовком мало б виникнути бажання прочитати текст твору, аби з'ясувати, як чином треба поводитися 3 Фортуною та чи варто кидати ій виклик. Отже, у першій частині заголовку горизонт авторських сподівань і горизонт читацького очікування мають точку перетину: авторові вдається заінтригувати потенційного читача, який сподівається знайти у книзі відповіді на гостроактуальні питання.

Другий блок назви роману Г. Робертса («проголошений Андруджіо, шляхетним гериогом Саксонським, який розповідає про нещастя, постійні зіткнення 3 мінливою Фортуною та вигнання, якого зазнав він сам, його дружсина $i$ діти») постає як певна конкретизація першого. Автор свідомо формує в читацькій уяві негативну ауру навколо спроб людини активно протистояти власній Долі. При цьому він використовує висхідну градацію (нещастя - зіткнення - вигнання), яка дозволяе посилити емоційну напругу. $\mathrm{He}$ можна виключати, що до такого художнього прийому Робертса міг підштовхнути добре знаний в Англії француз П'єр де Ронсар. Адже представник славнозвісної Плеяди у «Промові проти Фортуни», наголошував, що жодній 


\section{I. Історико-літературний процес}

людині ще не вдавалося перемогти у двобої з цією потужною і непередбачуваною силою.

Думається, що Г. Робертс навмисне протиставляє позитивно-оптимістичний пафос першої частини заголовку негативно-песимістичній тональності другої. Цим він намагається заінтригувати свого читача, спантеличити його суперечливими меседжами. Приголомшений читач змушений замислитись над тим, чому спочатку автор декларує в заголовку досить зухвалу думку про суперництво 3 Фортуною, а потім наголошує на неможливості протистояти їй. Тут, як бачимо, певний розрив між горизонтами авторських сподівань і читацьких очікувань дозволяє ще більше посилити інтригу.

Поєднання двох взаємовиключних меседжів, які формують у читача амбівалентне уявлення про Фортуну, робить назву роману Г. Робертса оригінальнішою за назви вищезгаданих творів його сучасників Р. Гріна, Дж. Лілі та Б. Мелбенка. Річ у тім, що за часів Ренесансу Фортуна сприймалася як ірраціональна й неконтрольована сила, іманентна природа якої стала об’єктом осмислення італійських гуманістів, а згодом й інтелектуальної еліти інших європейських країн. Ставлення людини до Фортуни поступово перетворювалося не лише на сферу особливого інтересу, але й на точку перетину полярних життєвих імперативів ${ }^{32}$ Декларуючи амбівалентність уявлень про Фортуну, Робертс формує у свідомості читача дві полярні моделі відношення до неї. У такий спосіб письменник реалізує одразу декілька цілей: підвищує самооцінку читача, нібито запрошуючи його відрефлектувати цікаву інтелектуальну проблему, породжує у нього бажання придбати книгу, а також ставить свій твір в один ряд із романами інших єлизаветинців.

32 Дет. див.: Буркхардт Я. Культура Италии в эпоху Возрождения [пер. с нем. А. Е. Махова]. - М. : Интрада, 1996. - 527 с. 
Tарасенко Кирил. Заголовки романів письменника-єлизаветинця Генрі Робертса ....

Отже, представлений аналіз дозволяє нам дещо скоригувати раніше розглянуту класифікацію заголовків, додавши до вже відомих типів - часопросторового, алюзивного, лінгвістичного, інтертекстуального, смислового, концептуального - ще один тип - комерційноорієнтований заголовок, який містить чіткі апеляції як до гостроактуальної проблематики, так і до певної категорії читачів. Такі заголовки дозволяють не лише загострити інтригу, але інколи, навіть, створити літературну містифікацію $^{33}$.

Третій блок заголовку роману Генрі Робертса («Додається опис благородних війн Галастіно, геризога Міланського, який мститься підступним саксонцяя за несправедливість»), з одного боку, пунктирно окреслює одну із сюжетних ліній твору, а 3 іншого боку, ніби заспокоює збентеженого читача тим, що справедливість може бути поновлена. Втім, у читача може виникнути питання, а чому виправити ситуацію намагається якийсь Галастіно, а не головний герой роману Андруджіо, на долю якого випало багато випробувань. Отже, тут Робертс, як бачимо, йде в річищі національної літературної традиції, якій була притаманна описовість у назвах творів (Дж. Лілі, Ф. Сідні, Т. Лодж, Р. Грін, Т. Делоні, Т. Неш, Е. Манді), але при цьому він порушує

33 Зазначимо, що в добу Відродження літературна містифікація була одним iз найпоширеніших письменницьких прийомів, що сприяли інтригуванню потенційного читача. Правомірно вести мову про, як мінімум, два різновиди тогочасних літературних містифікацій. Перший полягав у тому, що автор підписував свій твір лише ініціалами. Саме цей прийом і використав Генрі Робертс у романі «Виклик Фортуні». До речі, до подібної містифікації нерідко вдавалися також і його сучасники, зокрема Джордж Петті («Малий палац насолоди Петті», 1576), і Джордж Гаскойн («Пригоди добродія F.J», 1573). Другим різновидом літературної містифікації було введення читача в оману стосовно авторства твору, коли письменник у передмові представляв власний твір як чужий. Приміром, Томас Лодж презентував свій роман «Американська Маргарита» (1596) як рукопис, знайдений у Сарагосі. 


\section{I. Історико-літературний прощес}

логіку представлення сюжету, свідомо закладаючи певну невідповідність читацьким очікуванням. Очевидно письменник розраховував на те, що заінтригований читач придбає роман «Виклик Фортуні...» хоча б заради того, щоб знайти відповіді на спровоковані заголовком питання.

Крім того, у другому та третьому блоках заголовку міститься чимало жанрових маркерів, характерних для «високого» роману: це топоніми інших країн (Саксонський, Міланський), італізовані імена (Андруджіо, Галастіно) та декларації благородного походження героїв (герцог Саксонський, герцог Міланський). Відчутне тут і прагнення Робертса долучитися до когорти професійних письменників, які дію в своїх «високих» романах переносили в екзотичні простори або за межі Туманного Альбіону. Нагадаємо, що в «Евфуесі» Джона Лілі події розгортаються в Неаполі, Роберт Грін представляє персонажів роману «Пандосто» на тлі Богемії та Сіцилії, а сюжетні перипетії «Американської Маргарити» Томаса Лоджа розвиваються в екзотичному просторі нещодавно відкритих земель.

Другий i третій блоки заголовку роману $є$ поліфункціональними: окрім сюжетного вектору, вони містять також і певну інтригу, i «шокотерапію» для читача, ніби підвищуючи його статус до елітарного. Подібна сюжетно-ігрова функція заголовку свідчить про творчий характер пошуків автора та значно розширює наші уявлення про традиції називання художніх творів за часів Ренесансу..

Четвертий блок заголовку роману Г. Робертса (« ... 8 якому зображено благородне терпіння, рідкісний зразок благопристойнӧ̈ стриманості та ідеальний зразок справжньої дружби. Дуже приємний та насичений nерипетіями») акцентує увагу на вишуканості текстового наративу, який претендує на певну близькість до атмо- 
сфери «високого» роману. Про це свідчить ряснота епітетів, які формують у читацькій свідомості очікування, що у творі йтиметься про високих героїв та високі мотиви: "noble patience" («благородне терпіння»), "а most rare example of modest chastity" ("рідкісний зразок благопристойної стриманості»), "the perfect patterne of true friendship" («ідеальний зразок справжньої дружби»), "verie delectable” («дуже чарівний»). Водночас автор надає своєму читачеві - представнику середнього класу єлизаветинського суспільства - можливість відчути себе людиною, яка, подібно до представників вищих верств, спроможна читати i насолоджуватися високими романами. Письменник також знаходить вдалий спосіб натякнути читачеві про наявність у творі авантюрного компоненту. Якщо інші єлизаветинські літератори зазвичай використовували у заголовку слово “adventures",34, то Робертс знаходить інший спосіб зацікавити читацьку авдиторію. Він зазначає, що його твір «насичений перипетіями» (очевидно, маючи на увазі перипетії долі) i таким чином налаштовує майбутнього реципієнта на те, що у творі той неодмінно знайде цікаві пригоди, заплутані авантюри та хвилюючі сюжетні ходи.

Отже, у четвертому блоці заголовку горизонт авторських сподівань та горизонт читацького очікування перетинаються: Робертс звертається до читача так, як це робили автори тогочасних елітарних романів. Велика кількість слів 3 позитивно забарвленою семантикою (noble, rare, perfect, delectable) при цьому покликана посилити відчуття причетності як автора твору, так і його

34 Згадаймо, приміром романи Дж. Гаскойна "The adventures of Master F. J." («Пригоди добродія F. J.», 1573) або Барнабі Річа "The straunge and wonderfull aduentures of Don Simonsdes..." («Дивні та чудові пригоди Дона Сімонідеса», 1581), "The Second Tome of the Trauailes and aduentures of Don Simonides...” («Другий том подорожей і пригод Дона Сімонідеса», 1584). 


\section{I. Історико-літературний прощес}

потенційного читача до елітарної публіки. Цей блок забезпечує виконання заголовком комерційної функції.

На відміну від заголовку першого роману Г. Робертса, назва його другого роману складається лише 3 двох досить лаконічних частин: «Феандер, Цнотливий Лицар: опис його иляхетних подорожей $i$ зухвалих перемог у битвах та успішного кохання») ("Pheander, The Maiden Knight: describing his honourable travels and haughty attempts in armes, with his successe in love"') ${ }^{36}$. Це, як думається, може свідчити про поступовий відхід автора від багатослівності й риторичності, характерних для раннього єлизаветинського роману. Очевидно, що тут Робертс йде у річищі національної літературної традиції: згадаймо, приміром, назви таких романів як «Евфуес. Анатомія розуму» (1578) Дж. Лілі; «Філоцімус. Війна між Природою та Фортуною» (1583) Б. Мелбенка, «Нещасливий мандрівник, або життя Джека Вілтона» (1593) Т. Неша, «Пандосто: Тріумф Часу» (1588) Р. Гріна; «Розалінда. Золотий спадок Евфуеса» (1590) Т. Лоджа; «Пірс Простак: сім років служби підмайстра» (1595) Г. Четтла).

У першу частину заголовку твору винесено чоловіче ім'я - Феандер, яке супроводжується оціночною характеристикою - «цинотливий лицар». Подібно до Дж. Лілі («Евфуес», 1578); Е. Манді («Зелото», 1580) і Р. Гріна («Пандосто», 1578), Робертс називає головного героя свого твору на античний манер, віддаючи данину тогочасній літературній моді. Оціночний супровід («ц̧нотливий лиц̧ар»), вочевидь, мав викликати у читачів асоціації 3 середньовічними рицарськими романами:

\footnotetext{
${ }^{35}$ Roberts $H$. Pheander. The Maiden Knight // Henry Robarts' "Pheander. The Maiden Knight". Kritische Edition und Interpretation/ Inaugural-Dissertation zur Erlangung des Doktorgrades der Philosophischen Fakultät der Universität zu Köln / [vorgelegt von Klaus Dieter Matussek aus Gleitwitz]. - Köln : Universität zu Köln, 1974. - P. 1-190.

36 Тут і в подальшому переклад роману мій $-\boldsymbol{K} . \boldsymbol{T}$.
} 
згадаймо, приміром, такі популярні зразки цього жанру, як «Івейн, або Лицар зі Левом», «Ланселот, або лицар підводи» Кретьєна де Труа. Подібна літературна стратегія була спрямована на те, щоб вписати власний твір у традицію рицарських романів, для яких характерна саме така манера репрезентації протагоніста у заголовку. Ймовірно, що згаданий у заголовку концепт «цнотливості» наділений певною конотацією: імпліцитно налаштовуючи читача на зображення героя 3 чистими помислами та майже ідеальними рисами характеру, автор насамперед формує певну систему етико-психологічних координат, в якій буде розгортатися сюжет твору. Прикметно, що в тексті роману, а особливо у його фінальній частині вчинки Феандера суперечитимуть тим приписам поведінки, які закладає назва: цнотливий лицар буде переховуватися під виглядом купця, а ставши можновладцем роздаватиме землі своїм фаворитам і зрештою сподіватиметься обманним шляхом отримати гроші від співвітчизників. Отже, якщо номінально протагоніст роману ідентифікуватиме себе як лицар, то сутність деяких його вчинків контрастуватиме 3 рицарським кодексом честі. У першій частині заголовку автор також використовує гру як маніпулятивну стратегію спілкування з читачем, чий «горизонт очікувань» розходиться 3 «горизонтом авторських сподівань».

Друга частина заголовку («опис його иляхетних подорожей $i$ зухвалих перемог у битвах та успішного кохання» ${ }^{37}$ ) фіксує увагу читача на вже звичному наборі готових формул та стереотипних романічних колізій, таких як пригоди, авантюри i мандри. Як i в назвах романів Т. Неша («Безталанний мандрівник, або життя Джека Вілтона», 1593) і Г. Четтла («Пірс Простак: сім років служби підмайстра», 1595), друга частина

${ }^{37}$ Roberts H. Pheander. The Maiden Knight. 


\section{I. Історико-літературний прощес}

заголовку твору Робертса розшифровує першу. Згадка про «успішне кохання», яка у надзвичайно розгалуженій семантичній мережі єлизаветинських уявлень включала широкий діапазон імпліцитних смислів (від успішного шлюбу до вдалого втілення патріархальних практик підкорення суб'єкта), створює певну ігрову ситуацію. Згадка про цнотливість Феандера в першій частині назви вступає у діалогічні стосунки зі згадкою про успішне кохання. Як бачимо, автор не обмежується тільки сюжетною функцією заголовку, оскільки тут має місце гра 3 читачем. Тобто, як i в попередньому романі відбувається розширення функціонального потенціалу заголовку від сюжетного, за класифікацією А.Ламзіної, до сюжетно-ігрового.

Таким чином, аналіз заголовків двох романів пізньоренесансного письменника Генрі Робертса дає підстави стверджувати, що автор певною мірою виходить за межі усталеної традиції називання літературних творів, яка була сформована його попередниками - єлизаветинськими романістами. У творі «Виклик Фортуні» заголовок є $\mathrm{i}$ декларативно-метафоричним, i сюжетно-ігровим, i комерційно-орієнтованим водночас, оскільки кожна його частина несе певне семантичне навантаження. I хоча, на перший погляд, цей заголовок видається продуктом традиціоналістського типу художнього мислення, деякі суто авторські знахідки - як-от амбівалентність концепту Фортуни або маніпулятивна гра 3 читачем за рахунок маркерів «високого роману» - дозволяють побачити в ньому витоки індивідуально-авторського типу художнього мислення. До того ж, вміле рекламування власного твору в комплексі із підвищенням статусу реципієнта свідчить про креативність автора, який, хоч і не належав до першого ряду єлизаветинських літераторів, однак також мав власну читацьку авдиторію. Його твори 
служили аналогом того, що згодом назвуть «популярною літературою».

Заголовок роману «Феандер. Цнотливий Лицар» окрім власне сюжетної функції виконує ще й ігрову функцію, яку забезпечують елементи алюзивності. На відміну від першого твору, Робертс робить назву більш лаконічною. Однак йому і цього разу вдається заінтригувати читача, викликати у нього певні асоціації та жанрові очікування.

Оригінальність жанрової природи єлизаветинських романів в цілому, і Робертсових зокрема, забезпечується також і специфічною рамковістю текстових конструкцій (наявністю передмов, присвят, звернень до читача тощо). Такі наративно-композиційні техніки - прояви паратекстуальності, що були обов'язковим атрибутом ренесансних романів, безрепечно заслуговує на подальше дослідження ${ }^{38}$.

${ }^{38}$ Одним із перших кроків у цьому напрямку стала стаття: Тарасенко К. $B$. Передмови для англійських романів XVIII ст. як простір жанрологічних рефлексій // Держава та регіони: науково-виробничий журнал. Серія: «Гуманітарні науки» / гол. ред. Н. М. Торкут. - Запоріжжя: КПУ. - 2018. № 3 - C. 21-25. 